ICID: 1133206

DOI: $10.5604 / 12314005.1133206$

\title{
THE INFLUENCE OF CUTTING PARAMETERS ON CUTTING FORCES AND SURFACE ROUGHNESS
}

\author{
Wojciech Labuda \\ Gdynia Maritime University, The Faculty of Marine Engineering \\ Morska Street 83, 81-225 Gdynia \\ tel.: +48586901549, fax: +48586901399 \\ e-mail:wlabuda@am.gdynia.pl
}

\begin{abstract}
One of the greatest problems of modern production techniques is the achievement of an appropriate quality at minimal costs and accompanied by the production efficiency increase. Therefore, while designing the production process, the technology used should have a considerable influence on the durability and reliability of machine parts to be produced. During finish treatment, the final dimensions as well as functional properties are imparted to a given element by application of proper treatment type. The engineer has a range of production techniques to choose for the proper surface layer formation. It is crucial to find a suitable solution which will meet the requirements as well as the work conditions of a given machine part.

The article presents the preliminary research results referring to the analysis of the influence of finishing lathing on the cutting forces and surface roughness of steel. The research was performed on a roller 39 mm in diameter made of S235JR steel. The finish tooling of pump shaft pins was carrying out on a universal centre lathe. The finish lathing process was carried out by means of a CCMT $09 T 304$ PF Sandvik Coromant cutting tool with replaceable inserts. During the research, the effect of changes in the depth of cut on the value of cutting forces and temperature was defined. In addition, the influence of the depth of cut on the surface roughness was determined.
\end{abstract}

Keywords: turning dynamometer, cutting forces, cutting temperature, surface roughness

\section{Introduction}

One of the greatest problems of modern production techniques is the achievement of an appropriate quality at minimal costs and accompanied by the production efficiency increase. Therefore, while designing the production process, the technology used should have a considerable influence on the durability and reliability of machine parts to be produced. During finish treatment, the final dimensions as well as functional properties are imparted to a given element by application of proper treatment type. The process engineer has a range of production techniques to choose for the proper surface layer formation. It is crucial to find a suitable solution which will meet the requirements as well as the work conditions of a given machine part. The traditional finish treatment methods of marine pump shafts include grinding and finish turning. Industrial requirements make it necessary to reach the surface of high precision (3-5 accuracy class) simultaneously ensuring the roughness of $R_{a}=0.16-0.01 \mu \mathrm{m}$. Such an effect can be obtained by proper treatment methods of high accuracy.

One of the most important stages of forecasting tasks for improving the quality of use of machinery and equipment is the development of methods to control their durable - reliable characteristics. The object must properly fulfil its tasks under certain conditions and time [8]. Research shows that nearly $80 \%$ of the damage of machine parts has its beginning in the surface layer, and $50 \%$ of the kinetic energy is lost to overcome the frictional resistance [9]. The manufacturing process of machine parts is related to formation of the technological surface layer. Ensure appropriate design, materials and manufacturing technologies should provide the desired initial state of the workpiece $[1,2]$. The most common and universal way to remove layers of abraded material is the process of cutting. 
For the basic method of the surface layer, forming of shaft pins is known lathing. Conventional machining accuracy is usually considered as a function of the characteristics of all the components of machine tool, fixture, object, tool. There is accuracy performance, and the accuracy of static and dynamic determining and cutting parameters, which are associated with strength, temperature and wear of the cutting edge. Therefore, stock removal of high efficiency should be performed in a controlled manner, which ensures the correct shape and size of the chip.

The article presents the preliminary results of measurements of the forces and cutting temperatures for turning shafts made of structural steel at normal quality. The aim of this study was to determine the repeatability and the possibility of measuring by the gauge DKM 2010. The dynamometer is the equipment of Gdynia Maritime University. In addition, the effect of depth of cut on surface roughness was determined.

Many scientific centres, including the Gdynia Maritime University, deal with issues related to the turning surface of the difficult-to-machine [3-7]. Completed tests are also lathing of shaft pins made of stainless steel.

\section{Samples preparation}

The process of finish machining of shaft pins $\phi 39 \mathrm{~mm}$ in diameter (Fig. 1), made of S235JR steel was carried out on a universal CDS $6250 \mathrm{BX}-1000$ centre lathe. The lathing process was conducted by a cutting tool with CCMT 09T304 - PF removable plates. During the lathing, the following machining parameters were used: cutting speed $\mathrm{V}_{\mathrm{c}}=150 \mathrm{~m} / \mathrm{min}$, feed $\mathrm{f}=0.106 \mathrm{~mm} / \mathrm{rev}$, cutting depth $\mathrm{a}_{\mathrm{p}}=0.5,0.75,1.0,1.25,1.5,1.75 \mathrm{~mm}$. The shaft used in research is presented in Fig. 1.

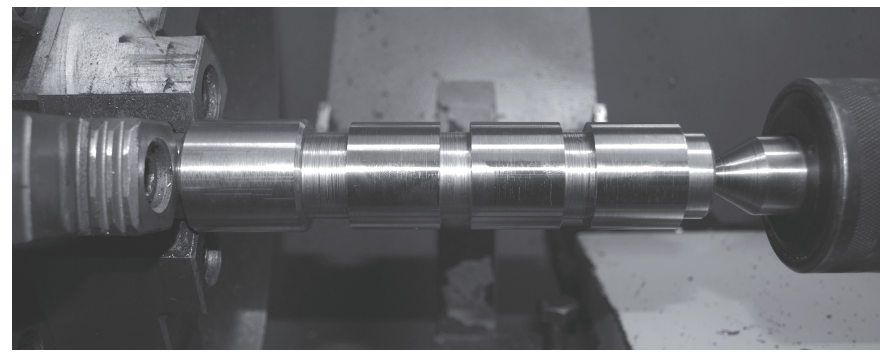

Fig. 1. Sample used in the resarch

\section{Research methodology}

DKM 2010 is a 5-components Tool Dynamometer for use on conventional or CNC lathe machines. The complete equipment of DKM 2010 is presents to Fig. 2.

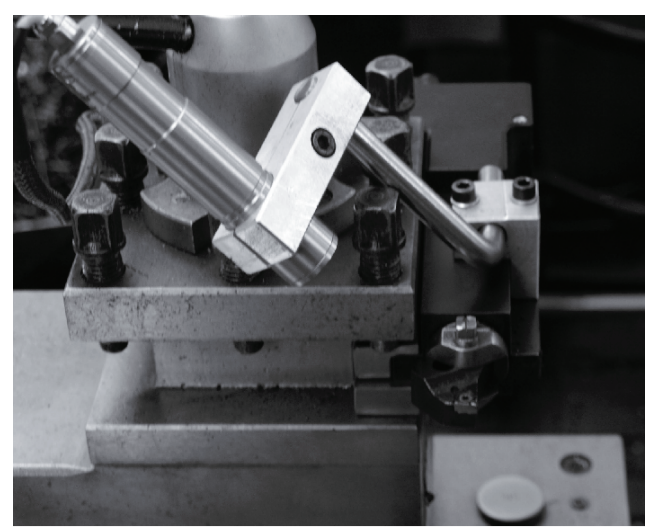

Fig. 2. Turning dynamometer DKM 2010 
It measures force on the cutting tool up to $2000 \mathrm{~N}$ with a resolution of $0.1 \%$ and as option also temperatures on the tool tip between 300 and $800^{\circ} \mathrm{C}$. The temperature measurement is based on radiation principle on a spot not greater than $2 \mathrm{~mm}$. DKM 2010 is equipped with adjustable inserts - holder to change side angle $x_{\mathrm{r}}$ into $45,60,70,90^{\circ}$. The surface topography was measured by T8000 profilometer.

\section{Research results}

During the preliminary tests conducted longitudinal turning the shaft with a depth of cut $a_{p}=0.50,0.75,1.00,1.25,1.5$ and $1.75 \mathrm{~mm}$. For each depth of cut made three attempts to turning with fixed parameters of cut. Fig. 3, 4, 5 shows the effect of depth of cut on the change in the value of cutting force $\left(\mathrm{F}_{\mathrm{c}}\right)$, feed force $\left(\mathrm{F}_{\mathrm{f}}\right)$ and radial force $\left(\mathrm{F}_{\mathrm{p}}\right)$. In contrast, in Fig. 6 shows the effect of depth of cut on the change in temperature on the rake face plate removable cutting tool at a distance of $2 \mathrm{~mm}$ from the cutting edge. The cutting process was carried out dry.

Analysis of influence changes in the depth of cut on cutting forces showed that with increasing the value of $a_{p}$ is an increase in the cutting force and feed force. Changing the depth of cut of $0.25 \mathrm{~mm}$ cause an average increase in force $F_{c}$ and $F_{f}$ the value of $100 \mathrm{~N}$. At the same time, increasing the value of the parameter $\mathrm{a}_{\mathrm{p}}$ leads to decrease in the value of the radial force of $25 \mathrm{~N}$.

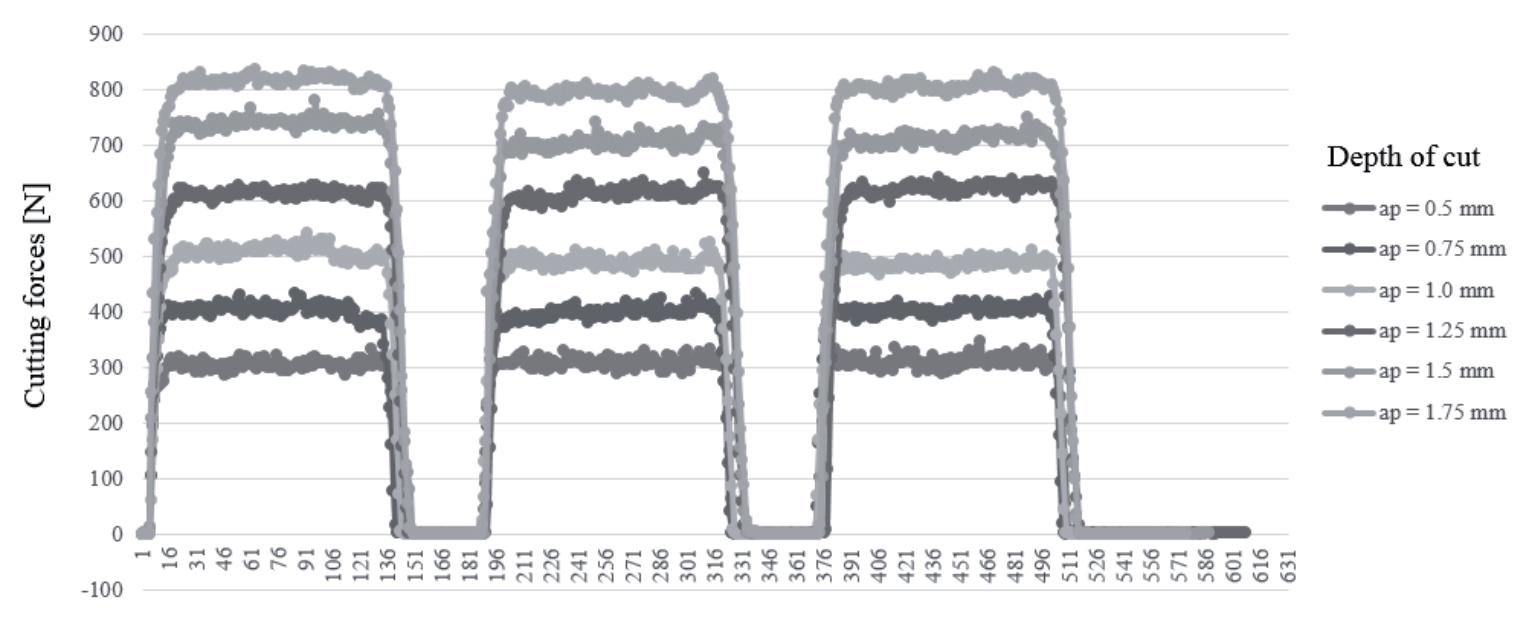

Number of samples

Fig. 3. Cutting forces

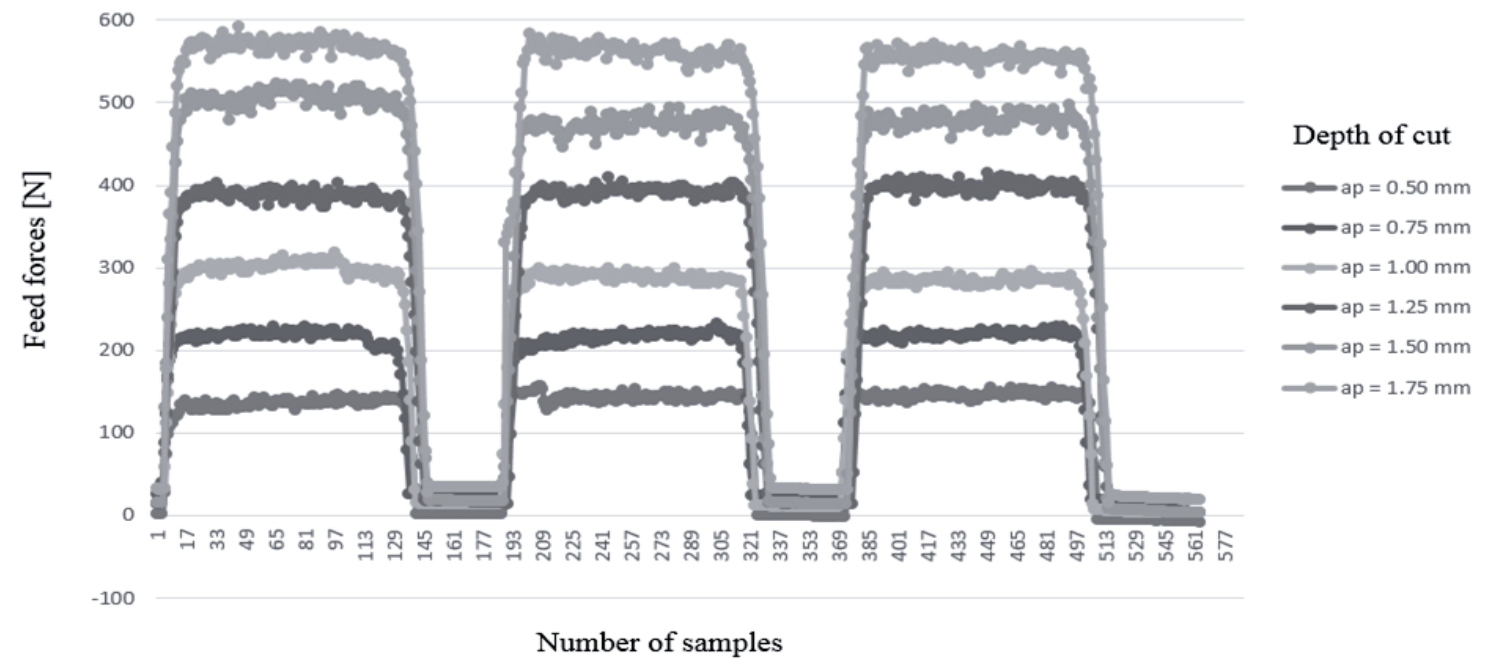

Fig. 4. Feed forces 


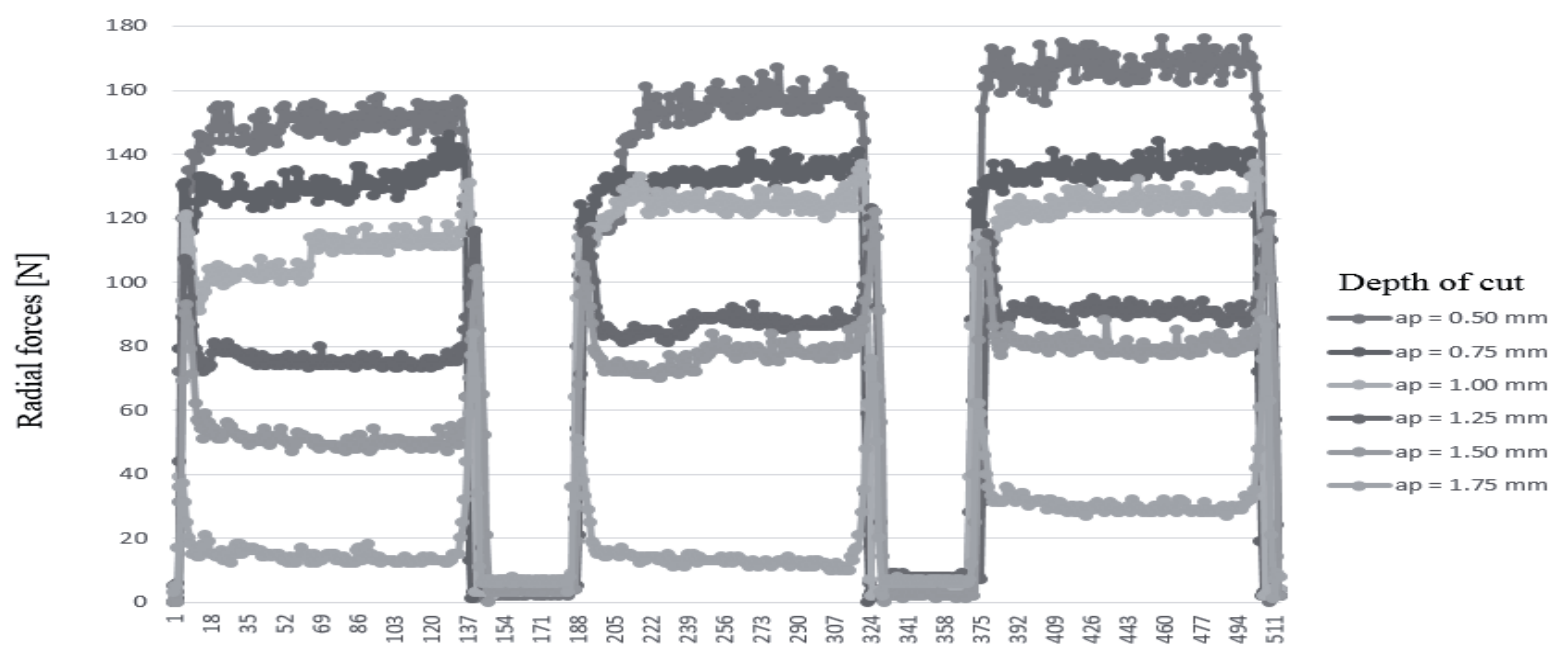

Number of samples

Fig. 5. Radial forces

The results of statistical analysis for cutting, feed and radial forces were presented in Tab. 1-3. The greatest value of the standard deviation obtained for the depth of cut equal to $1.5 \mathrm{~mm}$, which can provide the lowest stability of the cutting tool. The results of measurements for the study of the influence the depth of cut on the radial forces showed the biggest differences in the values for each shaft pins.

Tab. 1. The results of statistical analysis of cutting forces $-F_{c}$

\begin{tabular}{|l|l|l|l|l|l|l|}
\hline \multirow{2}{*}{$\mathrm{F}_{\mathrm{c}}[\mathrm{N}]$} & \multicolumn{7}{c|}{ Depth of cut $[\mathrm{mm}]$} \\
\cline { 2 - 8 } & 0.5 & 0.75 & 1 & 1.25 & 1.5 & 1.75 \\
\hline Mean & 308 & 402 & 494 & 614 & 717 & 805 \\
\hline Minimum & 286 & 371 & 445 & 511 & 679 & 777 \\
\hline maximum & 346 & 433 & 542 & 649 & 780 & 836 \\
\hline Stand. Dev. & 9.5 & 10.4 & 13.8 & 12.1 & 18.3 & 11.8 \\
\hline Stand.Error & 0.5 & 0.5 & 0.7 & 0.6 & 1.0 & 0.6 \\
\hline
\end{tabular}

Tab. 2. The results of statistical analysis of feed forces $-F_{f}$

\begin{tabular}{|l|c|c|c|c|c|c|}
\hline \multirow{2}{*}{$\mathrm{F}_{\mathrm{f}}[\mathrm{N}]$} & \multicolumn{7}{|c|}{ Depth of cut $[\mathrm{mm}]$} \\
\cline { 2 - 7 } & 0.5 & 0.75 & 1 & 1.25 & 1.5 & 1.75 \\
\hline Mean & 142 & 217 & 291 & 392 & 486 & 562 \\
\hline Minimum & 127 & 199 & 262 & 373 & 412 & 535 \\
\hline maximum & 157 & 232 & 318 & 414 & 523 & 592 \\
\hline Stand. Dev. & 6.0 & 5.6 & 9.2 & 7.6 & 16.8 & 9.7 \\
\hline Stand.Error & 0.3 & 0.3 & 0.5 & 0.4 & 0.9 & 0.5 \\
\hline
\end{tabular}

Tab. 3. The results of statistical analysis of radial forces $-F_{p}$

\begin{tabular}{|c|c|c|c|c|c|c|}
\hline \multirow[t]{2}{*}{$\mathrm{F}_{\mathrm{p}}[\mathrm{N}]$} & \multicolumn{6}{|c|}{ Depth of cut [mm] } \\
\hline & 0.5 & 0.75 & 1 & 1.25 & 1.5 & 1.75 \\
\hline Mean & 158 & 133 & 119 & 84 & 69 & 19 \\
\hline Minimum & 141 & 116 & 91 & 72 & 47 & 10 \\
\hline Maximum & 176 & 146 & 137 & 98 & 88 & 36 \\
\hline Stand. Dev. & 8.7 & 4.5 & 9.1 & 6.7 & 13.4 & 7.9 \\
\hline Stand.Error & 0.5 & 0.2 & 0.5 & 0.4 & 0.7 & 0.4 \\
\hline
\end{tabular}


The temperature distribution on the rake face of the turning tool for the cutting depth analysed ranged from 350 to $500^{\circ} \mathrm{C}$. With increasing depth of cut of the increased temperature on the rake face. Disruption temperature measurement shown on Fig. 6 was caused by the rise of continuous chip.

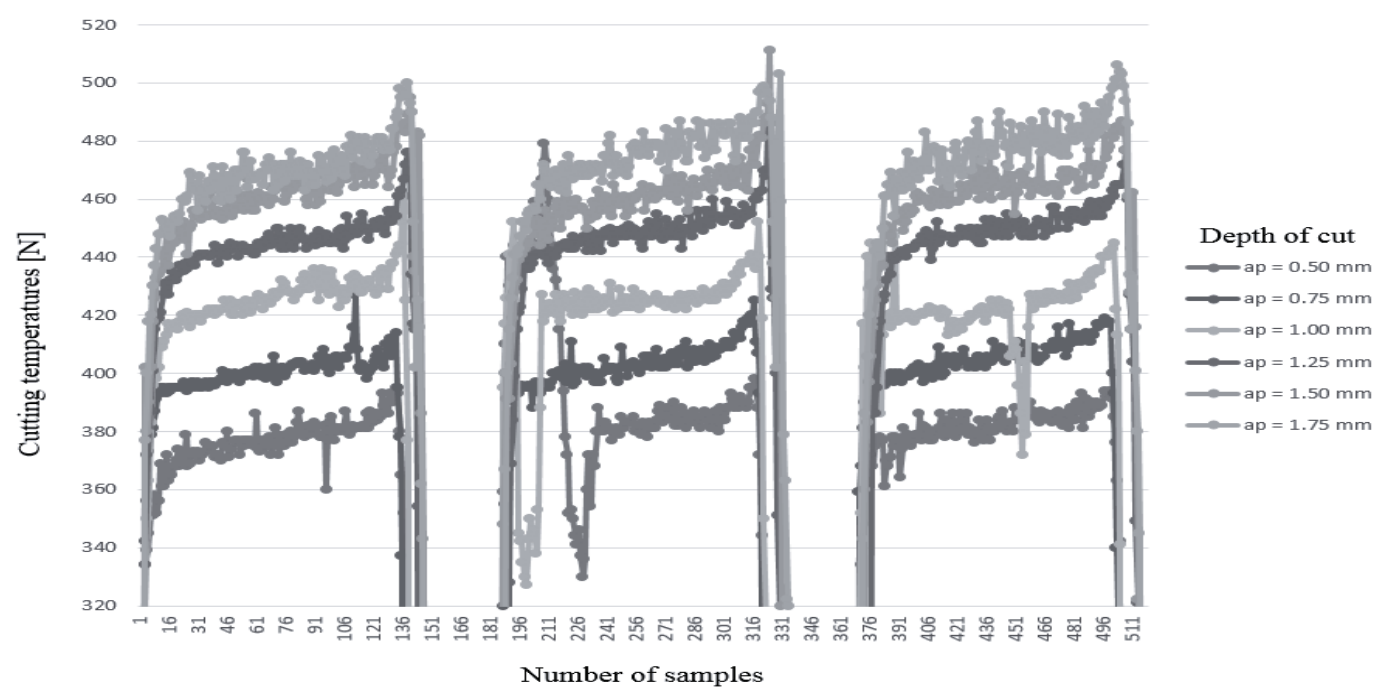

Fig. 6. Cutting temperatures

Table 4 shows the results of statistical analysis for the effect of the depth of cut on the surface roughness parameter $R_{a}$. The example shaft surface profile analysis for depth of cut is presents Fig. 7-9.

Tab. 4. The results of statistical analysis of surface roughness parameter

\begin{tabular}{|c|c|c|c|c|c|}
\hline Depth of cut & Mean & Minimum & Maximum & Stand. dev. & Stand. error \\
\hline 0.50 & 1.47 & 1.32 & 1.63 & 0.10 & 0.03 \\
\hline 0.75 & 1.51 & 1.46 & 1.57 & 0.04 & 0.01 \\
\hline 1.00 & 1.57 & 1.54 & 1.64 & 0.03 & 0.01 \\
\hline 1.25 & 1.55 & 1.50 & 1.61 & 0.04 & 0.01 \\
\hline 1.50 & 1.63 & 1.56 & 1.74 & 0.06 & 0.02 \\
\hline 1.75 & 1.67 & 1.61 & 1.78 & 0.06 & 0.02 \\
\hline
\end{tabular}

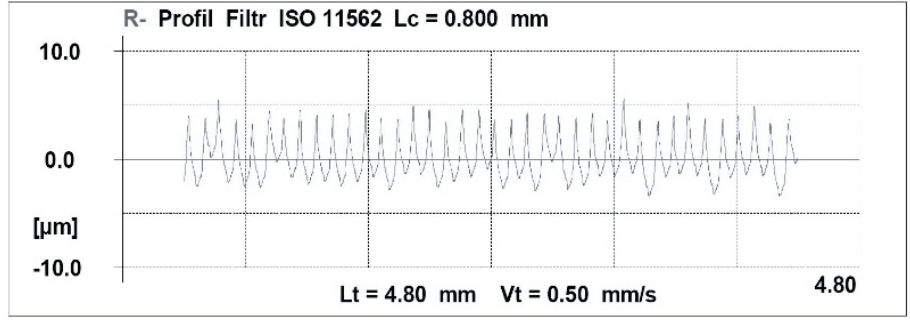

Fig. 7. The examples shaft surface profile analysis for depth of cut $a_{p}=0.75 \mathrm{~mm}$

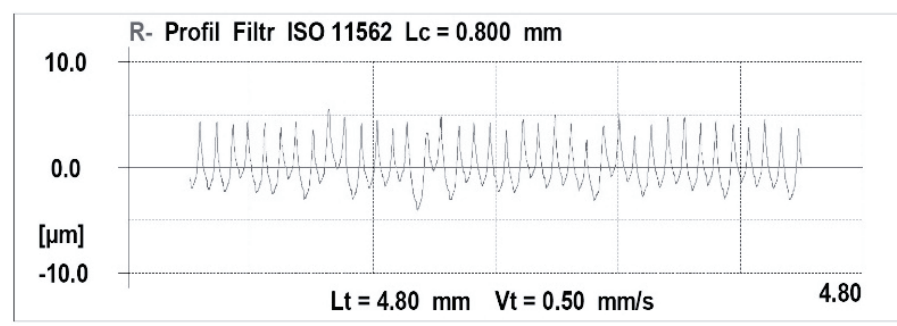

Fig. 8. The examples shaft surface profile analysis for depth of cut $a_{p}=1.25 \mathrm{~mm}$ 


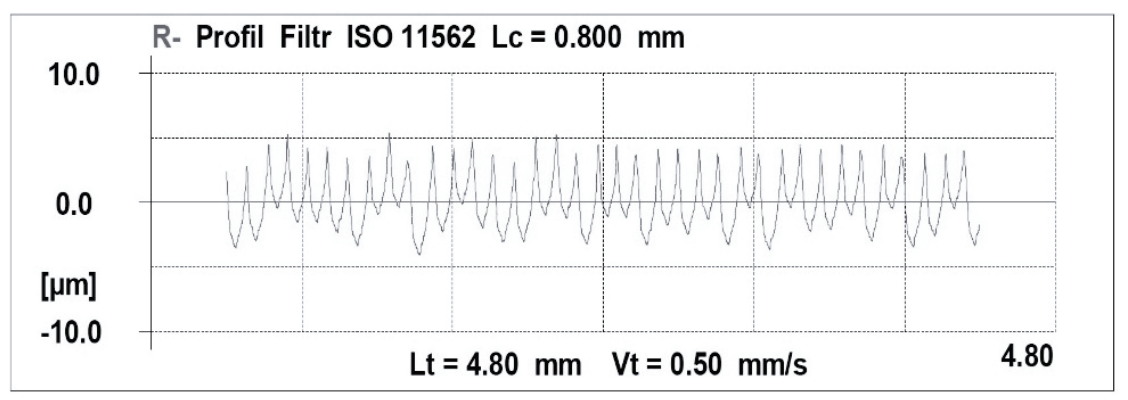

Fig. 9. The examples shaft surface profile analysis for depth of cut $a_{p}=1.75 \mathrm{~mm}$

\section{Conclusions}

An analysis of the results of the influence of depth of cut on the distribution of forces and cutting temperature confirmed the reproducibility of measurements using a dynamometer DKM 2010. In order to eliminate interference temperature measurements important role is played geometry of the cutting insert, which will allow forming of a discontinuous chip.

Increasing the depth of cut $\mathrm{a}_{\mathrm{p}}$ increases the value of the parameter $\mathrm{R}_{\mathrm{a}}$.

\section{References}

[1] Burakowski, T,. Marczak, R., Eksploatacyjna warstwa wierzchnia i jej badanie, Zagadnienia Eksploatacji Maszyn, Nr 3, pp. 327-337, 1995.

[2] Burakowski, T., Marczak, R., Senatorski, J., Szumniak, J., Konstytuowanie eksploatacyjne warstwy wierzchniej $w$ procesie tarcia technicznie suchego, Problemy Eksploatacji, Nr 2, pp. 5-36, 1998.

[3] Dyl, T., Starosta, R., Określenie wpływu geometrii i rodzaju materiału płytek skrawajacych na topografie toczonych powłok kompozytowych, Inżynieria Materiałowa Nr 6, p. 701-704, 2012.

[4] Dyl, T., Starosta, R., Wptyw geometrii i gatunku płytek skrawajacych na strukture geometryczna toczonych powłok stopowych, Inżynieria Materiałowa Nr 4, pp. 395-398, 2011.

[5] Dyl, T., Finishing intermetallic coatings in order to reduce the surface roughness, Journal of KONES Powertrains and Transport, Vol. 20, No. 1, pp. 77-82, 2013.

[6] Dyl, T., The finishing of composite coatings in aspect of surface roughness reduction, Journal of KONES Powertrains and Transport, Vol. 20, No. 2, p. 75-81, 2013.

[7] Starosta, R., Dyl, T., Obróbka wykańczająca natryskiwanych płomieniowo powłok Ni-Al, ocena zużcia borazonowych ptytek skrawajacych, Tribologia, Teoria i Praktyka, $\mathrm{Nr} 4$, pp. 245-252, 2011.

[8] Szczerek, M., Wiśniewski, M., Tribologia i Tribotechnika, Wydawnictwo Instytutu Technologii Eksploatacji, Radom 2000.

[9] Szyc, M., Bartosik, P., Kukiełka, L., Komputerowe modelowanie i symulacja stanów deformacji $w$ warstwie wierzchniej wyrobów kulowanych, Wspótczesne problemy w technologii obróbki przez nagniatanie, Wydawnictwo Politechniki Gdańskiej, T. 2, pp. 249254, 2008. 